\section{Disillusionment and doubt undermine Kyoto's birthday bash}

\section{Quirin Schiermeier, Munich}

It was a rather forlorn party that took place last Thursday night at the Milan Conference Centre. On the penultimate day of the United Nations' climate talks, hundreds of delegates commemorated the sixth birthday of the Kyoto Protocol on Climate Change - but no one was quite sure if it was a jubilee or a funeral.

The subdued atmosphere at the ninth conference of parties to the Kyoto Protocol could be attributed in large part to rampant speculation that Russia may not ratify the treaty, meaning that it will not come into force (see page 756).

Partygoers no doubt also had their minds on the many alarming reports released at the meeting. The World Health Organization, for example, reported that climate change seems to be responsible for some 150,000 deaths each year - $\mathbf{a}$ figure that is expected to double by 2030 . Another group asserted that a mere $2{ }^{\circ} \mathrm{C}$ of warming over pre-industrial temperatures would be "intolerable" for the planet (see Nature 426, 486; 2003).

But there was some Christmas cheer for those in Milan. Some technical details of the protocol were finalized, such as a scheme in which industrial countries can acquire emissions credits for financing land-use projects that absorb carbon.

The European Union also pledged $€ 400$ million (US\$490 million) per year from 2005 to help poorer countries adapt to climate change by improving flood protection or irrigation, for example.

Non-governmental organizations applauded Europe's efforts but criticized the US delegation, which argued in favour of carbon sequestration over emissions cuts. "There is no choice between future technology and taking action now. We need both," says Alden Meyer, director of policy at the Union of Concerned Scientists in Washington DC.

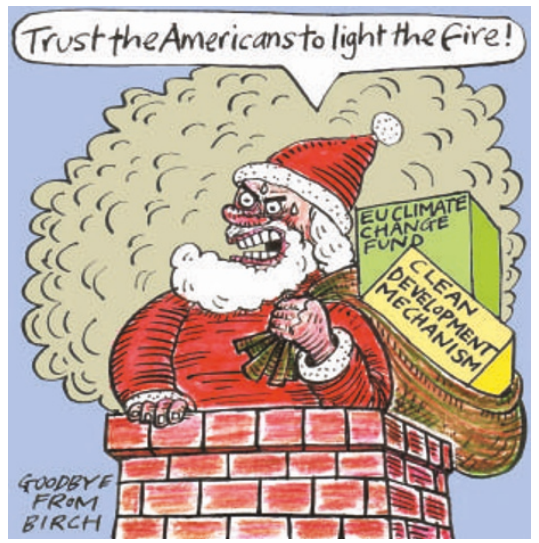

\title{
'Reverse genetics' could offer forward-thinking flu vaccine
}

Helen Pearson, New York

Health authorities are under renewed pressure to modernize influenza-vaccine production after an early surge in flu has highlighted shortfalls in the current jab.

Concerns about the vaccine were raised after an early and sudden start to the influenza season in Europe and the United States in late October. Public-health experts are still not sure whether the number of cases will go down - or rise to epidemic levels.

The spike in cases has highlighted two problems with the widely used inactivated influenza vaccine. First, the three virus strains in the vaccine exclude this season's predominant strain, a version of the $\mathrm{A}(\mathrm{H} 3 \mathrm{~N} 2)$ influenza subtype called Fujian. Publichealth officials say that the closely related Panama strain in the vaccine does confer some protection against the Fujian strain.

Second, parts of the United States have run short of the inactivated vaccine, for which the virus is mass-produced in hens' eggs. This has prompted the Centers for Disease Control and Prevention (CDC) in Atlanta, Georgia, to look for remaining stocks from US and foreign vaccine manufacturers.

Influenza experts at the World Health Organization (WHO) say that they knew the Fujian strain was circulating when they met in February 2003 to decide which strains to include in this season's Northern Hemisphere shot. The vaccine is regularly updated because the flu virus rapidly mutates to dodge our immune response. It shuffles two genes that encode proteins on the virus's coat, called haemagglutinin and neuraminidase.

But laboratories in the WHO's network failed to find a Fujian strain that would grow in fertilized hens' eggs in time to include in this season's vaccine. To make a suitable vaccine strain, researchers inject the circulating virus, such as Fujian, and another, fast-growing flu strain into eggs, where the two mix and match their genes.

From the eggs, scientists aim to pull out a new fast-growing reassorted virus - called a seed strain - which carries the haemagglutinin and neuraminidase genes from Fujian. Vaccine manufacturers need to receive the seed strain in time to grow it up in tens of millions of eggs, a process that is proven, efficient and reliable, but takes up to six months. "Using eggs does seem a bit like ancient technology," admits Alan Hay, who heads the WHO influenza collaborating centre in London.

Experts say that problems growing the Fujian strain could be bypassed using a technique called reverse genetics. Scientists could

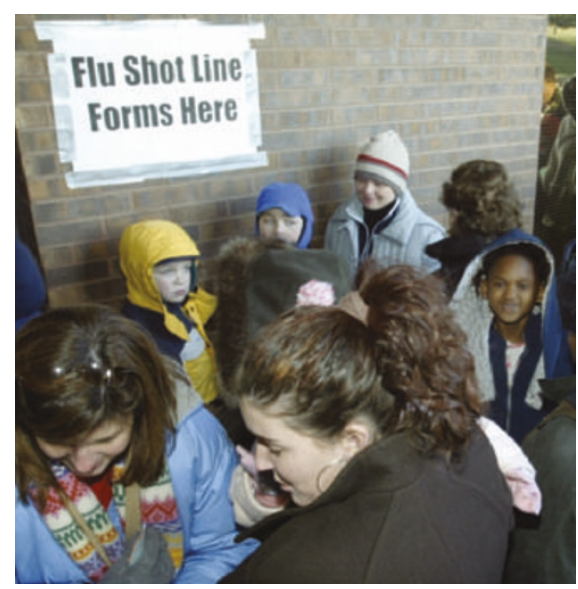

Feel the strain: publicly available flu jabs may not protect against this winter's predominant virus.

rapidly engineer the seed strain in the laboratory by stitching together the viral genes they want, and then use it to mass-produce the vaccine in hens' eggs.

Influenza vaccines made using reverse genetics have not yet progressed through clinical trials, however. And according to WHO officials and other experts, vaccine manufacturers might be dissuaded from using reverse genetics because they would owe licensing fees to MedImmune, a biotechnology firm based in Gaithersburg, Maryland that holds patents on the technique.

The WHO will organize a series of meetings between vaccine manufacturers, regulatory authorities and other parties in Geneva, Switzerland, in February 2004 to explore these issues, says Klaus Stohr, head of its influenza programme. The WHO is also working with the US National Institutes of Health to push ahead a clinical trial of a vaccine made using reverse genetics, which is expected to start in late 2004.

Experts say that flu vaccine could also be mass-produced in mammalian cell cultures, which could be set up for production in two weeks, whereas eggs have to be ordered at least six months in advance. "It can buy you some time," says Bram Palache at Solvay Pharmaceuticals, which is developing the technology at Weesp in the Netherlands.

Manufacturers have yet to prove that vaccines made in cell culture are as cheap as egg-made vaccines, but Palache predicts that they will be licensed and available in Europe by 2005 . And while updated techniques cannot make up for the vaccine shortfall this season, experts are keen to get them in place in time to combat future, more aggressive flu strains. "We are concerned that it be discussed before the pandemic," says Stohr. 